\title{
Serotonin Modulates Outward Potassium Currents in Mouse Olfactory Receptor Neurons
}

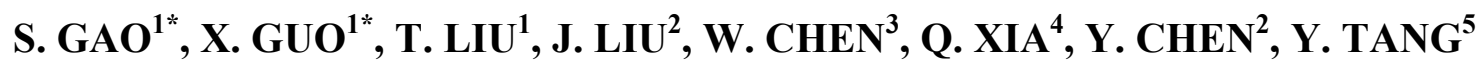 \\ ${ }^{*}$ These authors contributed equally to this work.
}

${ }^{1}$ Department of Otorhinolaryngology, West China Hospital of Sichuan University, Chengdu, Sichuan, P. R. China, ${ }^{2}$ Department of Anesthesiology and Critical Care Medicine, West China Hospital of Sichuan University, Chengdu, Sichuan, P. R. China, ${ }^{3}$ Department of Pathology, West China College of Public Health, Sichuan University, Chengdu, Sichuan, P. R. China, ${ }^{4}$ West China Laboratory of Molecular Genetics, Sichuan University, Chengdu, Sichuan, P. R. China, ${ }^{5}$ Department of Otorhinolaryngology and Translational Neuroscience Center, West China Hospital of Sichuan University, Chengdu, Sichuan, P. R. China

Received June 20, 2012

Accepted February 21, 2013

On-line April 16, 2013

\begin{abstract}
Summary
Monoaminergic neurotransmitter 5-hydroxytryptamine (5-HT), also known as serotonin, plays important roles in modulating the function of the olfactory system. However, thus far, the knowledge about $5-\mathrm{HT}$ and its receptors in olfactory receptor neurons (ORNs) and their physiological role have not been fully characterized. In the present study, reverse transcriptionpolymerase chain reaction (RT-PCR) analysis revealed the presence of $5-\mathrm{HT}_{1 \mathrm{~A}}$ and $5-\mathrm{HT}_{1 B}$ receptor subtypes in mouse olfactory epithelium at the mRNA level. With subtype selective antibodies and standard immunohistochemical techniques, both receptor subtypes were found to be positively labeled. To further elucidate the molecular mechanisms of 5- $\mathrm{HT}$ act on the peripheral olfactory transduction, the whole-cell patch clamp techniques were used on freshly isolated ORNs. We found that 5-HT decreased the magnitude of outward $\mathrm{K}^{+}$current in a dosedependent manner and these inhibitory effects were markedly attenuated by the $5-\mathrm{HT}_{1 \mathrm{~A}}$ receptor blocker WAY-100635 and the $5-\mathrm{HT}_{1 \mathrm{~B}}$ receptor antagonist GR55562. These data suggested that $5-\mathrm{HT}$ may play a role in the modulation of peripheral olfactory signals by regulating outward potassium currents, both $5-\mathrm{HT}_{1 \mathrm{~A}}$ and $5-\mathrm{HT}_{1 \mathrm{~B}}$ receptors were involved in this regulation.
\end{abstract}

\section{Key words}

Serotonin $\bullet$ ORNs $\bullet$ Whole-cell patch clamp $\bullet \mathrm{K}^{+}$channel

\section{Corresponding author}

Y. Tang, Department of Otorhinolaryngology and Translational Neuroscience Center, West China Hospital of Sichuan University, Chengdu, China. Fax: +86 028 85422436. E-mail: tangyd @hotmail.com

\section{Introduction}

Olfactory receptor neurons (ORNs) which typically respond to the presence of odorant with an increase in the frequency of firing of action potentials (Getchell 1986) are the key element of the olfactory pathway. The detection and discrimination of different odorant molecules are correlated with the electrophysiology of the olfactory receptor neurons. 5-HT exerts multiple biological functions including olfactory processing, by binding to cell surface receptors which can be classified into seven distinct families $\left(5-\mathrm{HT}_{1}\right.$ to $5-\mathrm{HT}_{7}$ ). With the exception of the $5-\mathrm{HT}_{3}$ receptors, which are ligand-gated ion channel, all of others are known to be seven transmembrane spanning G-protein coupled receptors (Pierce et al. 2002). The central olfactory system which includes the olfactory tubercle, the anterior olfactory nucleus, the piriform cortex, and the entorhinal cortex (Hamada et al. 1998), has been shown to contain significant amount of serotonergic neurons and 5-HT receptor subtypes (Takeuchi et al. 1982, McLean and 
Shipley 1987, Won et al. 1998, Bauman and Amaral 2005). The electrophysiological function of 5-HT was examined in olfactory system. For example, via $5-\mathrm{HT}_{1 \mathrm{~A}}$ receptors, 5-HT was reported to inhibit the neuronal excitability of the entorhinal cortex in the superficial layers by activating the TWIK-1 type of the two-pore domain $\mathrm{K}^{+}$channels (Deng et al. 2007). It also has been demonstrated that 5-HT causes reversible reduction of rapidly activating A-type $\mathrm{K}^{+}$current and delays rectifiertype $\mathrm{K}^{+}$conductance and voltage-activated $\mathrm{Ca}^{2+}$ influx in the antennal lobe cells of moths (Mercer et al. 1995). In addition, 5-HT depolarizes the juxtaglomerular cells by activating $5-\mathrm{HT}_{1 \mathrm{C}}$ receptors in the olfactory bulb, and the action of 5-HT in mitral cells of olfactory bulb contains two types of responses, hyperpolarized or depolarized (Hardy et al. 2005). These data indicate that 5-HT and its receptors may act a role in the olfactory system. However, the knowledge about 5-HT and its receptors in the peripheral olfactory system is limited.

As one of the major 5-HT receptor families, $5-\mathrm{HT}_{1}$ receptors were reported to be widely expressed in the olfactory regions of the brain where olfactory nerve projects to. $5-\mathrm{HT}_{1 \mathrm{~A}}$ receptors immunoreactivity has been observed in anterior olfactory nucleus, piriform cortex, entorhinal cortex and olfactory bulb (Pompeiano et al. 1994, Suehiro et al. 1998, Palchaudhuri and Flugge 2005, Muller et al. 2007). It was also reported that $5-\mathrm{HT}_{1 \mathrm{~B}}$ receptors were expressed high in olfactory tubercle (Bonaventure et al. 1998) and olfactory bulb (Pompeiano et al. 1994). However, there was no report concerning about the expression and distribution of $5-\mathrm{HT}_{1}$ receptors in mouse ORNs, although it was shown that the $5-\mathrm{HT}_{3 \mathrm{~A}}$ receptors were expressed predominantly in the basal layer of olfactory epithelium but not in the olfactory nerve (Johnson and Heinemann 1995).

The aim of the present study was to detect the expression and distribution of $5-\mathrm{HT}_{1 \mathrm{~A}}$ and $5-\mathrm{HT}_{1 \mathrm{~B}}$ receptor subtypes in olfactory epithelium. Moreover, we investigated the effect of exogenous 5-HT on the profile of the $\mathrm{K}^{+}$channel in acutely isolated ORNs, and studied the involvement of $5-\mathrm{HT}_{1 \mathrm{~A}}$ and $1 \mathrm{~B}$ receptors in such modulation.

\section{Materials and Methods}

\section{Animals and reagents}

The Kun-Ming (KM) mice, between 7-14 days old, were sacrificed in this study. Our experiment was approved by the animal care and use committee at the
Huaxi Medical School of Sichuan University, and our research was carried out in accordance with the National Institute of Health Guide for the Care and Use of Laboratory Animals (NIH Publications No. 80-23) in order to minimize the number of animals used and their suffering.

Trizol RNA isolation reagent was obtained from Roche (Switzerland). RT-PCR Kit was purchased from MBI (Lithuania). Taq enzyme, 5-HT, dNTPs were purchased from Sigma (St. Louis, USA). DNA Marker was from TianweiEra (Beijing, China). Anti-NF-L, anti-serotonin1A (5- $\left.\mathrm{HT}_{1 \mathrm{~A}}\right)$-receptor, anti-serotonin $1 \mathrm{~B}$ (5-HT $1 \mathrm{~B})$-receptor and biotin-labeled anti-rabbit IgG were purchased from Santa Cruz. SP Kit 9003 were obtained from Zhongshanjinqiao Biotechnology (Beijing, China). The DAB developer was from Pierce. Biotin-labeled anti-goat IgG was obtained from Jinmai Biotechnology (Tianjin, China). Pancreatic enzyme, 5-HT, WAY100635 and GR55562 were from Sigma (St. Louis, USA).

\section{Extraction of total RNA and RT-PCR}

The mice were deeply anesthetized with Nembutal (50 mg/kg, i.p.) and then decapitated. Total RNA was extracted from the freshly isolated olfactory epithelium using Trizol reagent. RT-PCR was carried out as we previously described (Long et al. 2008) using the following primer pairs: 5-HT $1 \mathrm{~A}$ receptors (Genbank number: NM_008308), forward primer 5'-CAGCTA CCAAGTGATCACCTCT-3' and reverse primer 5'-CTC ATGGTATCAGTGCTGGTC-3'; 5- $\mathrm{HT}_{1 \mathrm{~B}}$ receptors (Genbank number: NM_010482), forward primer 5'-ACC AAGTCAAAGTGCGAGTCT-3' and reverse primer 5'-ATCTGCAAGGATGCCTGCTG-3'. All primers were synthesized by Shanghai SAGON Company.

In this study, ascertained $5-\mathrm{HT}_{1 \mathrm{~A}}$ receptor positive cortex of frontal lobe tissues (Verge et al. 1986) and $5-\mathrm{HT}_{1 \mathrm{~B}}$ positive striatum tissues (Monsma et al. 1993) were used as positive controls. Ultra pure water (PCR grade, RNase-free) was as the negative controls.

\section{Immunohistochemistry}

The KM mice were anesthetized and decapitated rapidly. The nasal cavity was removed and then fixed in $4 \%$ neutral formalin for $48 \mathrm{~h}$, and decalcificated 48-72 h using EDTA decalcifying fluid. After rinsing, the nasal cavity was embedded in paraffin. Tissues were cut consecutively into $3-5 \mu \mathrm{m}$ slices and deparaffinized. Endogenous peroxidase activity was blocked with $3 \%$ 
hydrogen peroxide in distilled water for 15-20 min. After antigen retrieval in boiling autoclave for $2 \mathrm{~min}$, the sections were treated with $1 \%$ Triton X-100 at $4{ }^{\circ} \mathrm{C}$ for $10 \mathrm{~min}$, then rinsed with PBS for three times. To avoid nonspecific binding with primary antibodies, tissue sections were exposed to normal goat serum (1:20) for $10 \mathrm{~min}$, then lay in hatch base for $20 \mathrm{~min}$ at $37{ }^{\circ} \mathrm{C}$. Consequently, sections were incubated with primary antibodies, anti-neurofilament light chain (NF-L) antibody (rabbit anti- mouse $\mathrm{IgG}, 1: 200$ ), anti-5- $\mathrm{HT}_{1 \mathrm{~A}}$ receptor (goat anti-mouse $\mathrm{IgG}, 1: 200$ ), and anti-5- $\mathrm{HT}_{1 \mathrm{~B}}$ receptor (goat anti-mouse $\mathrm{IgG}, 1: 200$ ) respectively, then at $37^{\circ} \mathrm{C}$ in hatch base for $30 \mathrm{~min}$, followed by incubation at $4{ }^{\circ} \mathrm{C}$ moist chamber overnight. After rinsed for $5 \mathrm{~min}$ for three times with PBS, the sections were incubated at $37^{\circ} \mathrm{C}$ for $40 \mathrm{~min}$ with biotinylated anti-rabbit IgG (1:200), or biotinylated anti-goat $\operatorname{IgG}(1: 200)$. The sections were then rinsed in PBS three times, followed by adding streptavidin-biotin-peroxidase complex at $37{ }^{\circ} \mathrm{C}$ for $20 \mathrm{~min}$, rinsed with PBS four times. Finally the sections were stained with $\mathrm{DAB}$ solution, followed by counterstaining with hematoxylin and monitored under a microscope (Olympus, Japan) equipped with a camera connected to a computer. As negative controls, immunostaining of tissue sections was processed without primary antibodies.

\section{Dissection and identification of ORNs}

The dissection and identification of olfactory receptor neurons were conducted as described by $\mathrm{Ni}$ et al. (2008). The olfactory receptor neurons are bipolar neurons with an apical, ciliated dendritic region, a somata and a basal unmyelinated axon under an inverted microscope (Olympus, Japan) (Lucero and Chen 1997). They could create a $2 \sim 5 \mathrm{G} \Omega$ seal in the whole-cell mode.

\section{Whole-cell patch-clamp recordings}

The whole-cell patch-clamp technique was used to record membrane currents in olfactory receptor neurons. Cells were placed on the stage of an inverted Olympus IX70 microscope. Electrodes with resistances of $4 \sim 6 \mathrm{M} \Omega$ were pulled from borosilicate glass (outer diameter, $1.2 \mathrm{~mm}$ ) using a Narishige PC-10 electrode puller (Tokyo, Japan) and were filled with the electrode solution (in mmol/l): $145 \mathrm{KCl}, 4 \mathrm{MgCl}_{2}, 5.0 \mathrm{EGTA}$, 10 HEPES, 1 ATP and 0.1 GTP (PH 7.4 with $\mathrm{KOH})$. The extracellular solution contained (in mmol/l): $140 \mathrm{NaCl}$, $5 \mathrm{KCl}, 1 \mathrm{MgCl}_{2}, 1 \mathrm{CaCl}_{2}, 10$ HEPES, 10 glucose and 1 sodium pyruvate ( $\mathrm{PH} 7.4$ with $\mathrm{NaOH}$ ). The seal resistance was usually 1 to $10 \mathrm{G} \Omega$. Currents were monitored using an Axopatch 200B voltage amplifier (Axon Instruments, Union City, CA, USA), low pass filtered at $2 \mathrm{kHz}$, digitized with a Digidata 1200Axon A/D-D/A interface, acquired and analyzed with the aid of pCLAMP10.0 software (all from Axon Instruments). All experiments were performed at room temperature. Series resistances were compensated by $80 \%$. For the patchclamp recording, a neuron with smooth membrane, good refraction, and without intracellular Brownian motion was chosen. The morphological condition of the neuron was closely monitored during the course of experiment to ensure it remained healthy.

\section{Data analysis}

The effects of drugs were analyzed with the current density. Data were analyzed using Clampfit (version 10.0, Axon Instruments), SPSS13.0, and Excel (Microsoft). Data are expressed as the mean \pm standard error. The paired Student's $t$-test was used to determine the effects of drugs. Increases or decreases in outward potassium currents were considered to be statistically significant at a value of $\mathrm{p}<0.05$. The $\mathrm{n}$ represents cell number.

\section{Results}

$m R N A$ expression of $5-H T_{1 A}$ and $5-H T_{1 B}$ receptors in olfactory epithelium

As shown in Figure 1, strong mRNA expression of $5-\mathrm{HT}_{1 \mathrm{~A}}$ and $5-\mathrm{HT}_{1 \mathrm{~B}}$ receptors was found in positive controls. On the contrary, nothing was amplified from the blank controls. The mRNA for $5-\mathrm{HT}_{1 \mathrm{~A}}$ (a $172 \mathrm{bp}$ PCR product) and $1 \mathrm{~B}$ receptor (a $169 \mathrm{bp}$ PCR product) subtypes was strongly amplified in olfactory epithelium. The transcript of a housekeeping gene, a 600-bp glyceraldehydes-3-phosphate dehydrogenase (GAPDH), served as internal control.

Distribution of $5-H T_{1 A}$ and $5-H T_{1 B}$ receptors in the olfactory epithelium

5-HT receptor subtypes $1 \mathrm{~A}$ and $1 \mathrm{~B}$ immunoreactivities were shown in the olfactory epithelium (Fig. 2). In the negative control in which the first antibodies were omitted (Fig. 2A), no staining was detected. Cell nuclei were counterstained with hematoxylin. The olfactory epithelium is pseudostratified and can roughly be divided into three layers: sustentacular cell layer (SCL), nerve cell layer (NCL), 
and basal cell layer (BCL). The apical wide sublayer is primarily made up by the cell bodies of sustentacular cells. NF-L, a low molecular weight of silk protein, is specifically present in neuronal cells. NF-L-expressing cells was intensively stained, which can be considered as an indication for NCL. On the other side, basal cells are situated at the base of the epithelium (Fig. 2B). As shown in Figure $2 \mathrm{C}$ and $2 \mathrm{D}, 5-\mathrm{HT}_{1 \mathrm{~A}}$ receptors were distinctly localized to the cell bodies presumably belong to the neurons zone (Fig. $2 \mathrm{C}$ ), while $5-\mathrm{HT}_{1 \mathrm{~B}}$ receptors were mainly on the neural dendrites and dendrite terminals of olfactory receptor neuron cells (Fig. 2D).

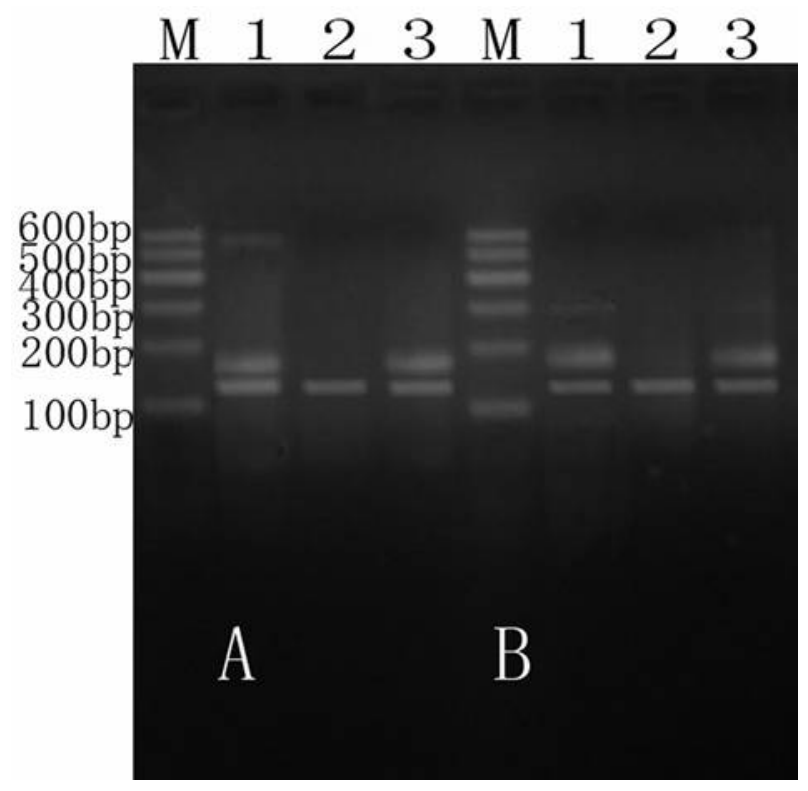

Fig. 1. A. $5-\mathrm{HT}_{1 \mathrm{~A}}$ receptor mRNA expression. Lanes: $M, 100 \mathrm{bp}$ marker; 1 , cortex of frontal lobe tissues (positive control); 2 , no cDNA template (negative control). 3, olfactory epithelium. B. $5-\mathrm{HT}_{1 \mathrm{~B}}$ receptor mRNA. Lanes: $\mathrm{M}, 100$ bp marker; 1 , striatum tissues (positive control); 2, no cDNA template (negative control); 3 , olfactory epithelium.

\section{Isolation of outward potassium currents}

The olfactory receptor neurons were held at a holding potential of $-100 \mathrm{mV}$, and depolarized between -70 and $+70 \mathrm{mV}$ (10 $\mathrm{mV}$ steps). To isolate voltage-gated $\mathrm{K}^{+}$from $\mathrm{Na}^{+}$currents and $\mathrm{Ca}^{2+}$ currents, tetrodotoxin $(0.1 \mu \mathrm{mol} / \mathrm{l})$ and $\mathrm{CdCl}_{2}(0.5 \mu \mathrm{mol} / \mathrm{l})$ were used in the extracellular solution (Fig. 3B). As shown in Figure 3D, the outward currents were strongly reduced by $15 \mathrm{mM}$ tetraethylammonium, a well known blocker of $\mathrm{K}^{+}$ channels (Fig. 3C was the control). In the following experiments, cells were bathed in extracellar solution containing tetrodotoxin $(0.1 \mu \mathrm{mol} / \mathrm{l})$ and $\mathrm{CdCl}_{2}$ $(0.5 \mu \mathrm{mol} / \mathrm{l})$ and with a normal pipette solution.

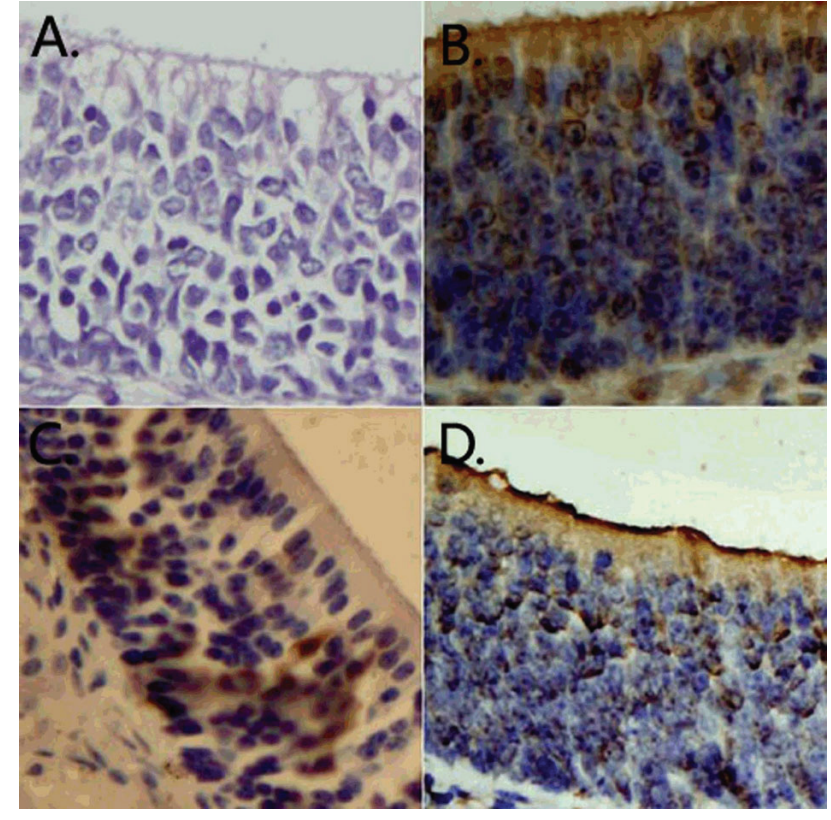

Fig. 2. A. Control (no primary antibody). B. Immunostaining for NF-L, a neuronal cell marker, used here to be considered as an indication for NCL. C. Immunohistostaining for $5-\mathrm{HT}_{1 \mathrm{~A}}$ receptor reveals an intracellular localization of the cell presumably belong to the neurons zone $(\times 200)$. D. Immunohistostaining for $5-\mathrm{HT}_{1 \mathrm{~B}}$ receptor shows the immunoreactivities mainly on the neural dendrite and dendrite terminals of ORNs $(\times 200)$.

Effect of 5-HT on the outward potassium currents of mouse olfactory receptor neurons

Mammalian ORNs respond to cell depolarization with an outward $\mathrm{K}^{+}$at least comprised two different currents, a fast transient component $\left(I_{\mathrm{A}}\right)$, as well as a slowly activating delayed rectifier $\mathrm{K}^{+}$currents component $\left(I_{\mathrm{K}}\right)$. As shown in Figure $4 \mathrm{~A}$ and $4 \mathrm{~B}$, the amplitude of voltage-gated $\mathrm{K}^{+}$channels, contained both two currents were reduced by application of 5-HT $(10 \mathrm{nmol} / \mathrm{l})$. Previous studies demonstrated that the fast transient component, but not the delayed rectifier $\mathrm{K}^{+}$currents component, could be abolished by setting the holding potential at $-40 \mathrm{mV}$. To isolate the delayed rectifier $\mathrm{K}^{+}$ currents component from the fast transient component, the olfactory receptor neurons were clamped at a holding potential of $-40 \mathrm{mV}$, depolarized by voltage steps from -20 to $+80 \mathrm{mV}$ in $10 \mathrm{mV}$ increments (Fig. 4C). The membrane capacitance of olfactory receptor neurons was $2.03 \pm 0.28 \mathrm{pF}$ ( $\mathrm{n}=43$ cells $)$.

As shown in Figure 4D, at a holding potential of $-40 \mathrm{mV}$, the delayed rectifier $\mathrm{K}^{+}$currents component was inhibited by 5 -HT $(10 \mathrm{nmol} / \mathrm{l})$. 5-HT reduced the magnitude of the delayed rectifier $\mathrm{K}^{+}$currents component from $1801.12 \pm 165.86 \mathrm{pA} / \mathrm{pF}$ to $1111 \pm 110.73 \mathrm{pA} / \mathrm{pF}$ $(\mathrm{n}=5, \mathrm{p}<0.05)$. The effect of 5 -HT on the fast transient component was determined by subtracting the delayed 


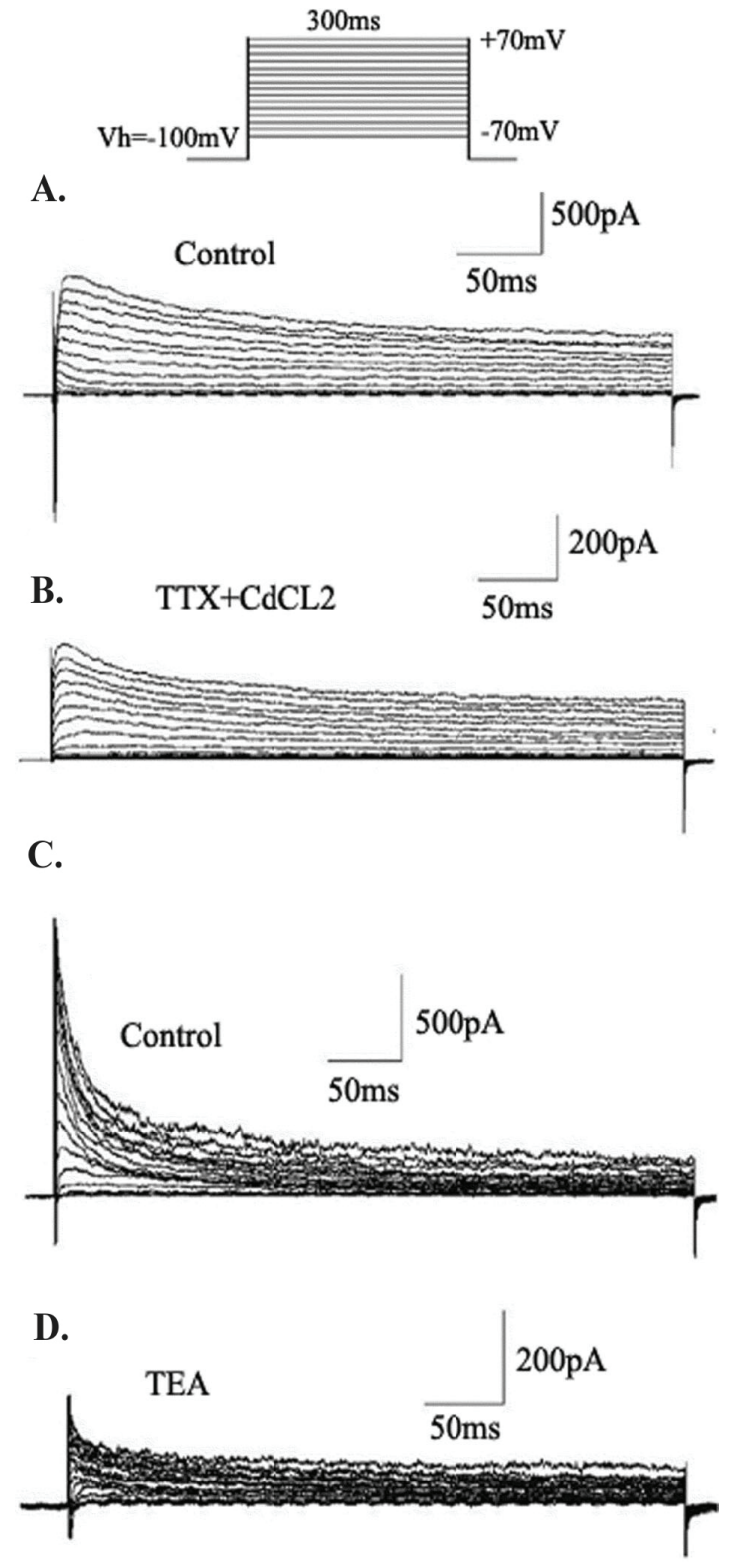

Fig. 3. Whole-cell voltage-gated currents in a mouse olfactory receptor neuron at a holding potential of $-100 \mathrm{mV}$, stimulating voltage from $-70 \mathrm{mV}$ to $+70 \mathrm{mV}$ in $10 \mathrm{mV}$ steps for $300 \mathrm{~ms}$. A. Voltage-gated currents were elicited in a mouse olfactory receptor neuron as described in the Methods. There were transient inward currents followed by outward currents. B. Voltage-gated $\mathrm{K}^{+}$channels were isolated by blocking $\mathrm{Na}^{+}$ currents with $0.1 \mu \mathrm{m} / \mathrm{l}$ tetrodotoxin and $\mathrm{Ca}^{2+}$ currents with $\mathrm{CdCl}_{2}$ $(0.5 \mu \mathrm{m} / \mathrm{l})$. C and D. The outward currents were strongly reduced when $15 \mathrm{~mm}$ tetraethylammonium, a well known blocker of $\mathrm{K}^{+}$channels, was applied to the bath, suggesting that the outward currents were potassium currents.

rectifier $\mathrm{K}^{+}$currents component elicited at a holding potential of $-40 \mathrm{mV}$ after application of 5-HT, from the currents recorded at the holding potential of $-100 \mathrm{mV}$ (Fig. 4B). By subtracting the delayed rectifier $\mathrm{K}^{+}$currents component from the currents, the calculation showed that 5-HT $(10 \mathrm{nmol} / \mathrm{l})$ reduced the amplitude of the fast transient component from $323.22 \pm 53.35$ to $177.49 \pm 50.05$

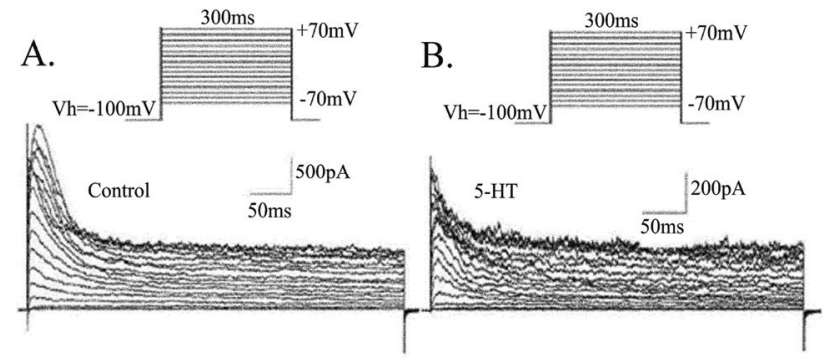

C.

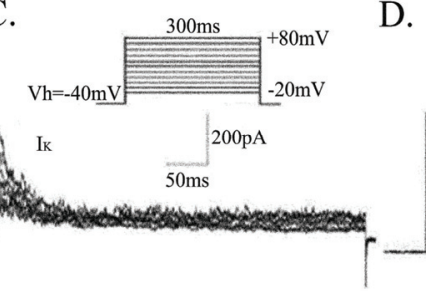

D.

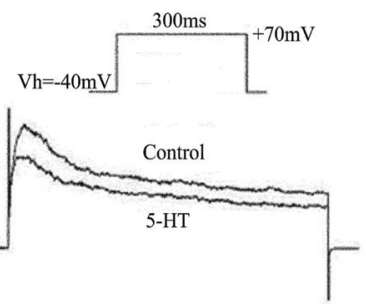

Fig. 4. A., B. The holding potential was $-100 \mathrm{mV}$ and the stimulating voltage was from $-70 \mathrm{mV}$ to $+70 \mathrm{mV}$ in $10 \mathrm{mV}$ steps for $300 \mathrm{~ms}$. A. The outward potassium currents were activated before application of 5-HT. B. Both the slowly activating delayed rectifier $\mathrm{K}^{+}$currents component and the fast transient component magnitudes were decreased following bath application of 5-HT. C. The outward potassium currents contain a fast transient component, as well as a delayed rectifier $\mathrm{K}^{+}$currents component. The delayed rectifier $\mathrm{K}^{+}$currents component was isolated by holding cells at $-40 \mathrm{mV}$ to various voltages between -20 and $+80 \mathrm{mV}$ in steps of $10 \mathrm{mV}$ for $300 \mathrm{~ms}$ in the same cell. D. The magnitude of delayed rectifier $\mathrm{K}^{+}$currents component was reduced after the application of 5-HT to the bath solution.

$\mathrm{pA} / \mathrm{pF}(\mathrm{n}=6, \mathrm{p}<0.05)$.

At the holding potential of $-100 \mathrm{mV}, 5-\mathrm{HT}$ ( $10 \mathrm{nmol} / 1,100 \mathrm{nmol} / 1,1 \mu \mathrm{mol} / \mathrm{l})$ reduced the magnitude of potassium in ORNs by $(38.55 \pm 4.40) \%(\mathrm{p}<0.05, \mathrm{n}=5)$, $(45.75 \pm 10.44) \% \quad(\mathrm{p}<0.05, \mathrm{n}=7)$ and $(56.43 \pm 6.01) \%$ $(\mathrm{p}<0.05, \mathrm{n}=10)$, respectively, in a dose-dependent manner (Fig. 5A).

Effect of 5-HT $T_{1 A}$ receptor antagonist on 5-HT induced inhibition of the potassium currents

To test the involvement of $5-\mathrm{HT}_{1 \mathrm{~A}}$ receptor in 5-HT-mediated blockage of the outward potassium currents, a selective $5-\mathrm{HT}_{1 \mathrm{~A}}$ receptor antagonist, WAY-100635 (5 nmol/1), was applied to the bath solution, and then 5-HT was added. The potassium currents were reduced from $326.47 \pm 89.07 \mathrm{pA} / \mathrm{pF}$ to $258.44 \pm 18.08 \mathrm{pA} / \mathrm{pF}$ at the holding potential of $-80 \mathrm{mV}$ and the stimulating potential of $+60 \mathrm{mV}$. The inhibitory effect of 5-HT $(10 \mathrm{nmol} / \mathrm{l})$ on potassium currents decreased from $(38.55 \pm 4.40) \%$ to $(26.00 \pm 6.67) \%$ with the treatment of WAY-100635 $(\mathrm{n}=7, \mathrm{p}<0.05) \quad$ (Fig. 5B). This result suggested that selective $5-\mathrm{HT}_{1 \mathrm{~A}}$ receptor antagonist WAY100635 could antagonize the inhibitory effect of 5-HT on olfactory receptor neuron outward potassium currents. 
Effect of 5-HT $T_{I B}$ receptor antagonist on 5-HT induced inhibition of the potassium currents

To determine whether the $5-\mathrm{HT}_{1 \mathrm{~B}}$ receptor also mediates the inhibition of 5-HT on outward potassium currents, we applied 5- $\mathrm{HT}_{1 \mathrm{~B}}$ receptor antagonist GR55562 (100 nmol/l) to the bath, then added 5-HT. The current density of potassium was reduced from $504.75 \pm 96.72 \mathrm{pA} / \mathrm{pF}$ to $344.58 \pm 58.18 \mathrm{pA} / \mathrm{pF}$. The inhibitory effect of 5-HT was significantly reduced from $(38.55 \pm 4.40) \%$ to $(26.52 \pm 7.87) \%$ with $100 \mathrm{nmol} / 1$ GR55562 pre-treatment $(\mathrm{n}=9, \mathrm{p}<0.05)$ (Fig. 5B). This result suggested that the $5-\mathrm{HT}_{1 \mathrm{~B}}$ receptor might also mediate the inhibition caused by 5-HT in olfactory receptor neurons.

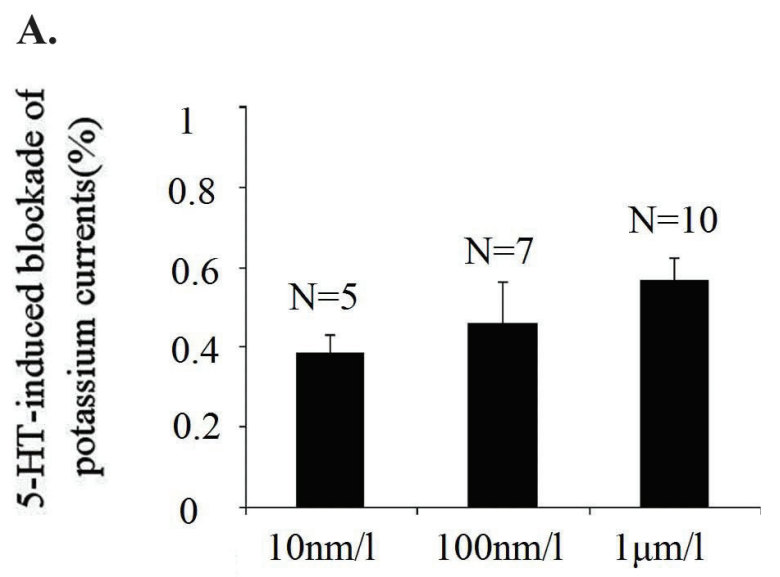

B.

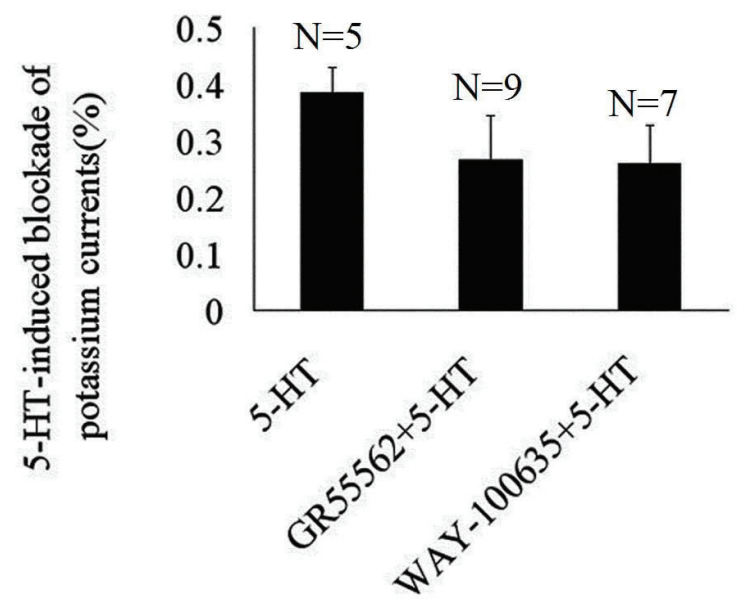

Fig. 5. A, B. The holding potential was $-100 \mathrm{mV}$ and the stimulating voltage was $+70 \mathrm{mV}$ for $300 \mathrm{~ms}$. A. Application of 5 - HT reduced the magnitude of outward potassium currents in a dose-dependent manner. B. The percentage reduction of $\mathrm{K}^{+}$ currents by $5-\mathrm{HT}$ treatment in the presence of GR55562 or WAY-100635. The inhibition by $5-\mathrm{HT}$ was attenuated from $(38.55 \pm 4.40) \%$ to $(26.00 \pm 6.67) \%$ with the addition of $100 \mathrm{~nm}$ GR55562 ( $n=9, p<0.05)$. The inhibitory effect of 5-HT $(10 \mathrm{~nm} / \mathrm{l})$ on potassium was reduced from $(38.55 \pm 4.40) \%$ to $(20.82 \pm 7.86) \%$ in the presence of WAY-100635 $(n=7, p<0.05)$.

\section{Discussion}

Types of currents in mouse olfactory receptor neurons have been described previously (Lagostena and Menini 2003). The $I_{\mathrm{A}}$ appeared in a huge amount of neurons and muscle, play critical role in determining the excitability of neurons (Han and Lucero 2006). The $I_{\mathrm{K}}$ helps determine the spike width and post-spike hyperpolariztion to sharp the maximal spike frequency of neurons (Gruhn et al. 2005). In the present study, we demonstrated that exogenous 5-HT reduced the magnitude of the outward potassium currents of mouse ORNs, both the amplitude of $I_{\mathrm{K}}$ and $I_{\mathrm{A}}$ were decreased. Although the physiological and pathological significance of the activation of potassium currents by serotonin is still unclear in the present investigation, the decrease in potassium currents appears to be responsible for the increased excitability in olfactory sensory neurons following application of 5-HT.

It was reported that $5-\mathrm{HT}_{1 \mathrm{~A}}$ receptors localized pre-synaptically on the cell bodies and dendrites of serotonergic neurons in the raphe nuclei and postsynaptically on many nonserotonergic neurons (Olivier and van Oorschot 2005). The post-synaptic 5-HT receptors have been reported to mediate decreases of neuronal firing in the pyramidal cells of the hippocampus and prefrontal cortex (Riad et al. 2000). Previous findings have provided evidence that the contributions of pre- and post-synaptic $5-\mathrm{HT}_{1 \mathrm{~A}}$ receptors to behavior can be dissociated (Ogren et al. 2008). In this study, the 5-HT $1 \mathrm{~A}$ receptors were localized to the cell bodies presumably belong to the neurons zone. Furthermore, preprocessed by $5-\mathrm{HT}_{1 \mathrm{~A}}$ receptor-selective antagonist WAY 100635 before application of serotonin abolished the decrease effect on the outward potassium currents. This result suggest that response to serotonin of ORNs was functionally mediated by $5-\mathrm{HT}_{1 \mathrm{~A}}$ receptors. $5-\mathrm{HT}_{1 \mathrm{~B}}$ receptors are also $\mathrm{G}$ protein-coupled receptor which are localized pre- and post-synaptically. In our present study, we demonstrated that $5-\mathrm{HT}_{1 \mathrm{~B}}$ receptors were mainly on the neural dendrites and dendrite terminals of ORNs, where the influence of cytoplasm washing out is delayed and limited. However, at the existence of GR55562, a $5-\mathrm{HT}_{1 \mathrm{~B}}$ receptor blocking drug, cells inhibition of $\mathrm{K}^{+}$ currents by 5 -HT was reduced. It is suggested that the $5-\mathrm{HT}_{1 \mathrm{~B}}$ receptor subtype may participate in the inhibitory effect of 5-HT on olfactory receptor neurons potassium currents. Serotonin translates information about behavioral context into changes in sensory processing via 
a diverse array of receptors, these receptors may interact to shape sensory encoding. These two receptors are G-protein coupled receptor and their activation is through a G-protein-mediated mechanism (Adayev et al. 2005), the precise mechanisms of serotonin and $5-\mathrm{HT}_{1 \mathrm{~A}}$ and $5-\mathrm{HT}_{1 \mathrm{~B}}$ receptors interaction in ORNs are still unclear. Whether it is through the same signal pathway requires to be clarified by further experiment.

In conclusion, this is the first study to characterize the regulation of 5-HT and its two receptor subtypes on the outward potassium current in the mouse ORNs. This study is an essential first step towards further understanding the cellular effects of 5-HT modulation of the periphery olfactory system. Further investigation of the regulatory molecules and intracellular signaling systems are imperative to be explored at a variety of levels biophysically and electrophysiologically.

\section{Conflict of Interest}

There is no conflict of interest.

\section{Acknowledgements}

This project was supported by the National Natural Science Foundation of China (30872844) and the Project of Scientific and Technical Supporting Programs of Sichuan province (2010SZ0172) to Dr. Yuedi Tang. The authors would like to thank Dr. Lili Long and Dr. Chao $\mathrm{Yu}$ for their excellent technical assistance and valuable advice regarding the paper, we thank Mr. Faqiang Zhang, Mr. Zengliang Xia and Mrs. Daqing Liao for their excellent technical assistance, also.

\section{References}

ADAYEV T, RANASINGHE B, BANERJEE P: Transmembrane signaling in the brain by serotonin, a key regulator of physiology and emotion. Biosci Rep 25: 363-385, 2005.

BAUMAN MD, AMARAL DG: The distribution of serotonergic fibers in the macaque monkey amygdala: An immunohistochemical study using antisera to 5-hydroxytryptamine. Neuroscience 136: 193-203, 2005.

BONAVENTURE P, VOORN P, LUYTEN WHML, JURZAK M, SCHOTTE A, LEYSEN JE: Detailed mapping of serotonin $5-\mathrm{HT}_{1 \mathrm{~B}}$ and $5-\mathrm{HT}_{1 \mathrm{D}}$ receptor messenger RNA and ligand binding sites in guinea-pig brain and trigeminal ganglion: Clues for function. Neuroscience 82: 469-484, 1998.

DENG PY, POUDEL KS, ROJANATHAMMANEE L, PORTER JE, LEI S: Serotonin inhibits neuronal excitability by activating two-pore domain $\mathrm{K}^{+}$channels in the entorhinal cortex. Mol Pharmacol 72: 208-218, 2007.

GETCHELL TV: Functional properties of vertebrate olfactory receptor neurons. Physiol Rev 6: 772-818, 1986.

GRUHN M, GUCKENHEIMER J, LAND B, HARRIS-WARRICK RM: Dopamine modulation of two delayed rectifier potassium currents in a small neural network. J Neurophysiol 94: 2888-2900, 2005.

HAMADA S, SENZAKI K, HAMAGUCHI-HAMADA K, TABUCHI K, YAMAMOTO H, YAMAMOTO T, YOSHIKAWA S, OKANO H, OKADO N: Localization of 5-HT2A receptor in rat cerebral cortex and olfactory system revealed by immunohistochemistry using two antibodies raised in rabbit and chicken. Mol Brain Res 54: 199-211, 1998.

HAN P, LUCERO MT: Pituitary adenylate cyclase activating polypeptide reduces expression of Kv1.4 and Kv4.2 subunits underlying A-type $\mathrm{K}+$ current in adult mouse olfactory neuroepithelia. Neuroscience 138: 411-419, 2006.

HARDY A, PALOUZIER-PAULIGNAN B, DUCHAMP A, ROYET JP, DUCHAMP-VIRET P: 5-hydroxytryptamine action in the rat olfactory bulb: In vitro electrophysiological patch-clamp recordings of juxtaglomerular and mitral cells. Neuroscience 131: 717-731, 2005.

JOHNSON DS, HEINEMANN SF: Embryonic expression of the 5-HT $\mathrm{H}_{3}$ receptor subunit, 5-HT $\mathrm{R}-\mathrm{A}$, in the rat: an in situ hybridization study. Mol Cell Neurosci 6: 122-138, 1995.

LAGOSTENA L, MENINI A: Whole-cell recording and photolysis of caged compounds in olfactory sensory neurons isolated from the mouse. Chem Senses 28: 705-716, 2003.

LONG LL, TANG YD, XIA QJ, XIA ZL, LIU J: Detection of atrial natriuretic peptide receptor in the labyrinth of the mouse inner ear. Neuro Endocrinol Lett 29: 577-580, 2008.

MCLEAN JH, SHIPLEY MT: Serotonergic afferents to the rat olfactory bulb: I. Origins and laminar specificity of serotonergic inputs in the adult rat. $J$ Neurosci 7: 3016-3028, 1987. 
MERCER AR, HAYASHI JH, HILDEBRAND JG: Modulatory effects of 5-hydroxytryptamine on voltage-activated currents in cultured antennal lobe neurones of the sphinx moth Manduca sexta. J Exp Biol 198: 613-627, 1995.

MONSMA FJ, SHEN Y, WARD RP, HAMBLIN MW, SIBLEY DR: Cloning and expression of a novel serotonin receptor with high affinity for tricyclic psychotropic drugs. Mol Pharmacol 43: 320-327, 1993.

MULLER CP, CAREY RJ, HUSTON JP, DE SOUZA SILVA MA: Serotonin and psychostimulant addiction: Focus on 5-HT ${ }_{1 \mathrm{~A}}$-receptors. Prog Neurobiol 81: 133-178, 2007.

NI MM, LUO Y, LIU J, LIAO DQ, TANG YD: FMRFamide modulates outward potassium currents in mouse olfactory sensory neurons. Clin Exp Pharmacol Physiol 35: 563-567, 2008.

OGREN SO, ERIKSSON TM, ELVANDER-TOTTIE E, D'ADDARIO C, EKSTROM JC, SVENNINGSSON P, MEISTER B, KEHR J, STIEDL O: The role of 5-HT(1A) receptors in learning and memory. Behav Brain Res 195: 54-77, 2008.

OLIVIER B, VAN OORSCHOT R: 5-HT1B receptors and aggression: A review. Eur J Pharmacol 526: $207-217,2005$.

PALCHAUDHURI M, FLUGGE G: 5-HT1A receptor expression in pyramidal neurons of cortical and limbic brain regions. Cell Tissue Res 321: 159-172, 2005.

PIERCE KL, PREMONT RT, LEFKOWITZ RJ: Seven-transmembrane receptors. Nat Rev Mol Cell Biol 3: 639-650, 2002.

POMPEIANO M, PALACIOS JM, MENGOD G: Distribution of the serotonin 5-HT 2 receptor family mRNAs: comparison between 5- $\mathrm{HT}_{2 \mathrm{~A}}$ and 5- $\mathrm{HT}_{2 \mathrm{C}}$ receptors. Mol Brain Res 23: 163-178, 1994.

RIAD N, GARCIA S, WATKINS KC, JODOIN N, DOUCET E, LANGLOIS X, EL MESTIKAWY S, HAMON M, DESCARRIES L: Somatodendritic localization of 5-HT1A and preterminal axonal localization of 5-HT1B serotonin receptors in adult rat brain. J Comp Neurol 417: 181-194, 2000.

SUEHIRO M, UNDERWOOD M, ARANGO V, WANG TS, KASSIR S, BAKALIAN M, YATABE T, PRATAP M, VAN HEERTUM RL, MANN JJ: In vivo biodistribution of a radiotracer for imaging serotonin-1A receptor sites with PET: [C-11]LY274601. Life Sci 63: 1533-1542, 1998.

TAKEUCHI Y, KIMURA H, SANO Y: Immunohistochemical demonstration of serotonin nerve-fibers in the olfactorybulb of the rat, cat and monkey. Histochemistry 75: 461-471, 1982.

VERGE D, DAVAL G, MARCINKIEWICZ M, PATEY A, EL MESTIKAWY S, GOZLAN H, HAMON M: Quantitative autoradiography of multiple 5- $\mathrm{HT}_{1}$ receptor subtypes in the brain of control or 5,7-dihydroxytryptamine-treated rats. J Neurosci 6: 3474-3482, 1986.

WON MH, OHNO T, SUH JG, LEE JC, JO SM, OH YS, NAMIKAWA T, KITOH J: Serotonergic neurons are present and innervate blood vessels in the olfactory bulb of the laboratory shrew, Suncus murinus. Neurosci Lett 243 : 53-56, 1998. 